\title{
Treatment of short stature in renal disease with recombinant human growth hormone
}

\author{
Lesley Rees, Susan P A Rigden, Geraldine Ward, Michael A Preece
}

\begin{abstract}
Six prepubertal children with chronic renal failure (group 1), six prepubertal children with renal transplants (group 2), and six pubertal children with renal transplants (group 3) who were short (mean height SD score, -3.2, range -4.5 to -1.6 ) and growing poorly (mean (range) growth velocity $(\mathrm{cm} /$ year) over the year before treatment: group 1, 4.8 (3.5$5.8)$, group $2,2.3(0.9-4.7)$, and group $3,3.2$ $(0.5-6.5))$ were treated with recombinant human growth hormone 30 units $/ \mathrm{m}^{2} /$ week in daily doses for a median of 0.98 years (range 0.25-0.99). Mean (range) growth velocity over the treatment period increased significantly in all groups (group 1, 10.7 (8.8-12.3), group 2, $6 \cdot 1(2 \cdot 7-10 \cdot 8)$, and group $3,6.0(4 \cdot 6-6 \cdot 8)$ ). There was, however, no improvement in height SD score for bone age in any group. The renal function of two children deteriorated after starting treatment with growth hormone, but it was not possible to say whether the growth hormone was responsible for this. The long term effects of treatment and its influence on final height are not yet known.
\end{abstract}

Short stature is a serious problem for children with chronic renal disease. Intensive conservative management of chronic renal failure ${ }^{1}$ early transplantation, ${ }^{2}$ and the use of lower doses of steroids since the introduction of cyclosporin ${ }^{3}$ have improved the growth prognosis for most children. There are still some children, however, whose growth fails to respond to these measures. ${ }^{12}$

Recombinant human growth hormone (rhGH) increases the rate of growth of short normal children, ${ }^{4}$ and produced significant improvements in growth in five children with chronic renal failure treated for six months. ${ }^{5} \mathrm{We}$ have therefore assessed the effect of pharmacological doses of rhGH given for a period of a year to short children with renal disease.

Children's Renal Unit, Evelina Children's Hospital, Guy's Hospital, London SE1 9RT Lesley Rees Susan P A Rigden Geraldine Ward Department of Growth and Development, Institute of Child Health, London

Michael A Preece

Correspondence to: Dr Rees.

Accepted 19 March 1990 and their diagnoses were dysplastic kidneys $(n=1)$, cystinosis $(n=2)$, focal segmental glomerulosclerosis $(n=1)$, unspecified glomerulonephritis $(n=1)$, and posterior urethral valve $(n=1)$. Group 3 were pubertal patients with renal transplants. Their mean age was 15.6 years (range 14.1-18.3), four were boys, and their diagnoses were dysplastic kidneys $(n=2)$, reflux nephropathy $(n=1)$, juvenile nephronophthisis $(n=1)$, posterior urethral valve $(n=1)$, and neonatal cortical necrosis $(n=1)$. The children all fulfilled the following criteria on entry to the study: they had all attended the clinic for at least 18 months and they were all short with height SD scores more than 2 SD below the mean $(n=17)$ or height velocity $S D$ scores more than $1 \mathrm{SD}$ below the mean $(n=12)$. None had diabetes, uncontrolled bone disease, nephrotic syndrome, or abnormal liver or thyroid function tests. All the patients with transplants were receiving prednisolone on alternate days in the morning. The mean (range) doses $\left(\mathrm{mg} / \mathrm{m}^{2}\right)$ were: group $2,14.9(10 \cdot 1-17 \cdot 6)$ and group $3,11 \cdot 0(8 \cdot 6-19 \cdot 4)$.

The study was approved by the hospital ethics committee, and informed consent was obtained from the parents. The children continued to attend the outpatient clinics as before.

\section{PHYSICAL ASSESSMENT}

Height (measured by the same observer (GW) with a Harpenden stadiometer), weight, and puberty stage $^{6}$ were assessed every three months. Bone age was assessed at the beginning and end of the year. ${ }^{7}$ Growth measurements were expressed as SD scores for chronological age and bone age, ${ }^{8}$ and as height velocity $(\mathrm{cm} /$ year). Blood pressure was measured at each visit, and the systolic pressure was used for comparisons.

BIOCHEMICAL AND HAEMATOLOGICAL ASSESSMENT

Blood was taken at entry to the study and then every three months for estimations of the concentrations of urea, electrolytes, creatinine, calcium, phosphate, bilirubin, albumin, haemoglobin, fasting blood glucose and glycated haemoglobin, the white cell and platelet counts, and the activities of alkaline phosphatase and aspartate aminotransferase. Glomerular filtration rate $\left(\mathrm{ml} / \mathrm{min} / 1.73 \mathrm{~m}^{2}\right)$ was calculated with the height/creatinine formula. ${ }^{9}$ Urine was collected on arrival at the morning clinic for measurement of the calcium:creatinine ratio. 
Table 1 Effect of recombinant human growth hormone on height SD score, bone maturation, and height velocity $S D$ score. Results are expressed as mean (range)

\begin{tabular}{|c|c|c|c|c|}
\hline & $\begin{array}{l}\text { Height } S D \text { score } \\
\text { for chronological age }\end{array}$ & $\begin{array}{l}\text { Bone age delay } \\
\text { (years) }\end{array}$ & $\begin{array}{l}\text { Height } S D \text { score } \\
\text { for bone age }\end{array}$ & $\begin{array}{l}\text { Height velocity } S D \\
\text { score for chronological } \\
\text { age }\end{array}$ \\
\hline $\begin{array}{l}\text { Group } 1 \text { : } \\
\text { At beginning of treatment } \\
\text { At end of treatment }\end{array}$ & $\begin{array}{l}-2 \cdot 9(-3.7 \text { to }-2 \cdot 3) \\
-2 \cdot 1(-3.0 \text { to }-1 \cdot 2)^{* *}\end{array}$ & $\begin{array}{l}-2.1(-4.2 \text { to }-0.5) \\
-1.6(-3.1 \text { to }-0.6)\end{array}$ & $\begin{array}{l}-1.1(-2.3 \text { to }-0.4) \\
-0.8(-2.0 \text { to } 0.3)\end{array}$ & $\begin{array}{r}-1.3(-2.5 \text { to }-0 \cdot 1) \\
6.0(4 \cdot 1 \text { to } 7 \cdot 5)^{* * * *}\end{array}$ \\
\hline $\begin{array}{l}\text { Group } 2 \text { : } \\
\text { At beginning of treatment } \\
\text { At end of treatment }\end{array}$ & $\begin{array}{l}-3 \cdot 3(-4 \cdot 5 \text { to }-1 \cdot 6) \\
-3 \cdot 1(-5 \cdot 4 \text { to }-1 \cdot 1)\end{array}$ & $\begin{array}{l}-2.5(-4.3 \text { to }-1.0) \\
-2.5(-4.5 \text { to }-0.3)\end{array}$ & $\begin{array}{l}-1.7(-2.7 \text { to }-0.5) \\
-1.4(-2.7 \text { to } 0.2)\end{array}$ & $\begin{array}{r}-2.0(-3.5 \text { to }-0.8) \\
0.6(-1.4 \text { to } 2.8)^{* * *}\end{array}$ \\
\hline $\begin{array}{l}\text { Group 3: } \\
\text { At beginning of treatment } \\
\text { At end of treatment }\end{array}$ & $\begin{array}{l}-3.4(-4.3 \text { to }-2.6) \\
-3.2(-3.6 \text { to }-2.4)\end{array}$ & $\begin{array}{l}-2.7(-5.4 \text { to }-1.2) \\
-2.9(-6.0 \text { to }-1.8)\end{array}$ & $\begin{array}{l}-1.1(-2.0 \text { to. } 1.4) \\
-1.0(-2.5 \text { to } 1.8)\end{array}$ & $\begin{array}{r}-1.0(-2.3 \text { to } 1.0) \\
3.5(0.2 \text { to } 11.4)^{*}\end{array}$ \\
\hline
\end{tabular}

${ }^{*} \mathrm{p}<0.05,{ }^{* *} \mathrm{p}<0.01$, and ${ }^{* * *} \mathrm{p}<0.0001$ compared with beginning of treatment within that group.

\section{HORMONAL ASSESS̄MENT}

Growth hormone pulsatility was assessed by 15 minute blood sampling from 2000 to 0700 in all patients except for one boy in group 2 in whom venous access was difficult. He was given clonidine $0.15 \mathrm{mg} / \mathrm{m}^{2}$ orally and samples were taken for baseline measurement of growth hormone and then half hourly for three hours. The methods used to compile the overnight profiles, the measurement of growth hormone concentrations, and their analysis by 'Pulsar' have been described previously. ${ }^{2}$ Insulin like growth factor 1 (measured by radioimmunoassay after acid-ethanol extraction ${ }^{2}$ ), thyroid function tests and parathyroid hormone concentrations measured by a two site immunochemiluminometric method (Ciba Corning Diagnostics)) were assessed at the beginning and end of the study.

\section{DIETARY ASSESSMENT}

Three day prospective dietary assessments were made at each clinic visit for the patients with chronic renal failure. Energy and protein intakes over the treatment period were compared with those during the year before treatment.

\section{ASSESSMENT OF TRANSPLANT DYSFUNCTION} Episodes of transplant dysfunction, defined as an episode treated with a three day course of prednisolone at a dose of $3 \mathrm{mg} / \mathrm{kg} / \mathrm{day}$, were counted for each child during the year before, and the year of, treatment.

\section{TREATMENT REGIMEN}

Each child received rhGH (Genotropin, KabiVitrum), 30 units $/ \mathrm{m}^{2} /$ week in daily doses subcutaneously for a median of 0.98 years (range $0 \cdot 25-0.99$ ). Growth hormone antibodies were measured at the beginning and end of the treatment period.

\section{STATISTICAL ASSESSMENT}

Results are expressed as mean or median (range). The significance of differences was assessed by the paired Student's $t$ test, and a probability of $<0.05$ was accepted as significant.

\section{Results}

GROWTH

Table 1 shows the changes in growth variables during the treatment period. Two patients stopped rhGH after three months (one in group 1 because of fear of needles, and one in group 3 because of non-compliance). They have been omitted from calculations of bone age. One boy in group 1 stopped after six months because he received a renal transplant. All children in groups 1 and 2 remained prepubertal. Two of the five adolescents in group 3 who received a year of rhGH treatment progressed through puberty by one stage, and in three the pubertal staging remained unchanged (median (range) genital or breast stage before receiving rhGH 2 (2-3), and after receiving rhGH $2(2-4)$ ). Height SD scores increased significantly in group 1 , and height velocity SD scores for chronological age increased significantly in all groups. The importance of this was difficult to assess in group 3, who may have been experiencing pubertal growth spurts. Bone age was delayed before treatment in all patients and remained delayed after treatment. Changes in bone age delay and height SD scores for bone age were not significant.

Individual growth velocities are shown in fig 1 for the year before treatment (median dura-



Figure 1 Changes in growth velocity over the year before growth hormone was started and during the treatment period; ${ }^{*}=$ treatment stopped after three months; ${ }^{*}=$ treatment stopped after six months. 
tion of period $1.06(0.92-1 \cdot 18)$ years $)$ and the treatment period (median duration 0.98 $(0.25-0.99)$ years). Growth rates for the three patients who did not complete a year of treatment were expressed as extrapolated annual growth rates. The changes in growth velocity were significant in each group. There was no correlation between the response to treatment and the severity of chronic renal failure in group 1 , or between the doses of steroids and the growth response in groups 2 and 3, or between growth hormone pulsatility and the growth response in all groups. No antibodies to growth hormone were detected in any child.

\section{RENAL FUNCTION}

The calculated glomerular filtration rate at the beginning and end of the treatment period is shown for each group in table $2 .^{8}$ There was no significant change in any group. The renal function of one child in group 1 and one in group 2, however, deteriorated. One adolescent in group 3 lost his transplant because he did not take his drugs regularly. The reciprocal of the plasma creatinine is shown plotted against time for the

Table 2 Glomerular filtration rate at the beginning and end of treatment with recombinant growth hormone. Results are expressed as mean (range)

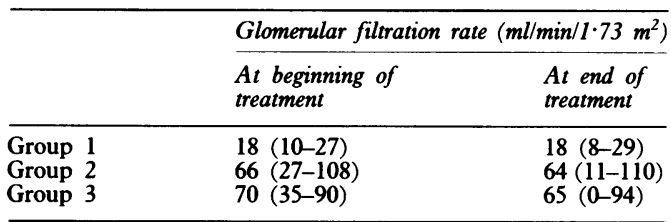

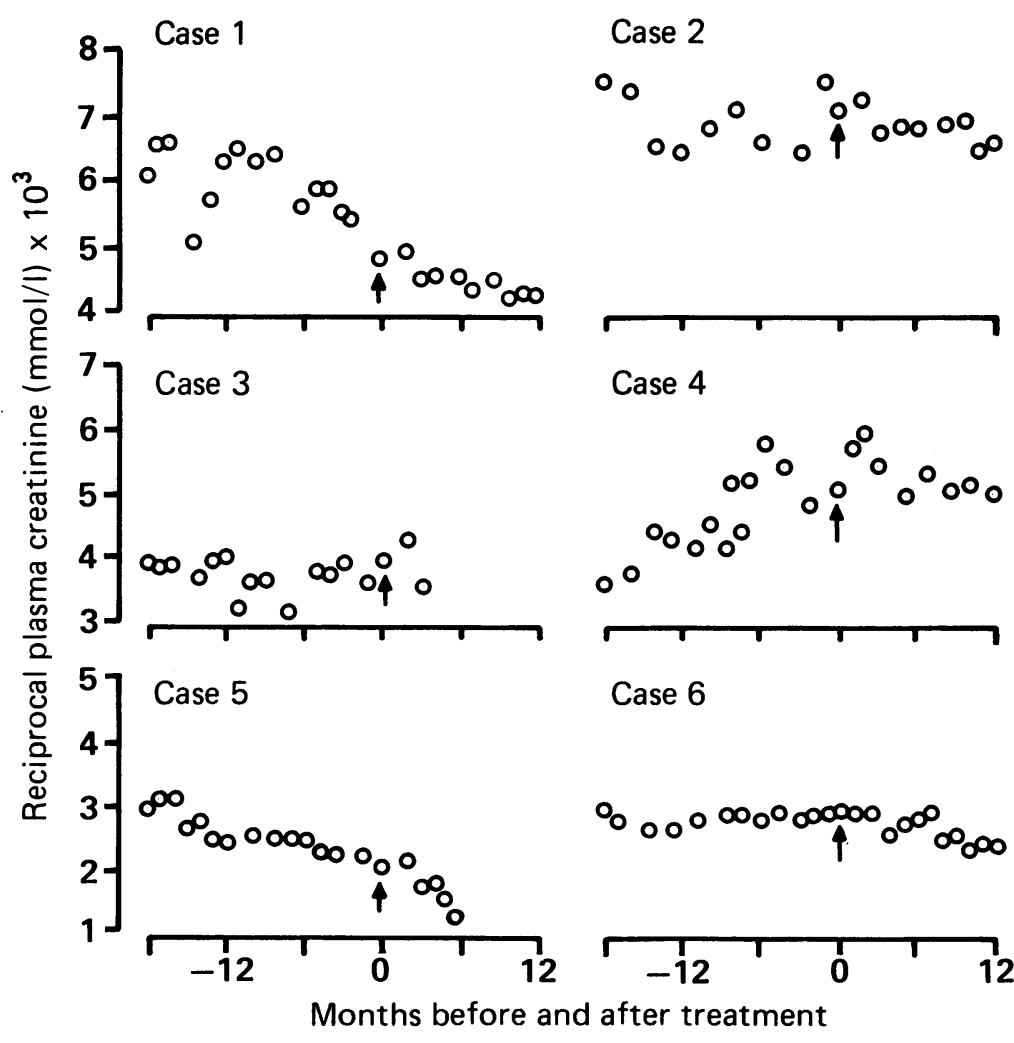

Figure 2 Reciprocal of plasma creatinine plotted against time in six children with chronic renal failure (group 1) before and after treatment with recombinant human growth hormone (beginning of treatment indicated by vertical arrow). six patients with chronic renal failure in fig 2 There was no consistent effect of rhGH. Case 5, whose calculated glomerular filtration rate decreased from 10 to $8 \mathrm{ml} / \mathrm{min} / 1.73 \mathrm{~m}^{2}$ received a transplant after six months of treatment. He had the lowest glomerular filtration rate of all the children at the beginning of treatment with rhGH. The glomerular filtration rate of the child in group 2 fell from 51 to $11 \mathrm{ml} / \mathrm{min} / 1 \cdot 73$ $\mathrm{m} .^{2}$ She had six episodes of transplant dysfunction treated with high doses of prednisolone during the year of treatment, but had also had five during the previous year. A transplant biopsy specimen showed no evidence of acute rejection, but chronic changes. Control of her blood pressure had also deteriorated. She was, however, the only child in the study in whom control of blood pressure became a problem, and there were no significant changes in blood pressure in any group. For all groups, mean systolic blood pressure $(\mathrm{mm} \mathrm{Hg})$ before treatment was 96 (range 80-130), and during treatment 101 (range 70-150).

There was no significant change in the number of episodes of transplant dysfunction/child during the year before $(1 \cdot 7,0-6)$ compared with during treatment with rhGH $(1 \cdot 5,0-6)$.

The urinary calcium:creatinine ratio was over $0.7 \mathrm{mmol} / \mathrm{mmol}$ in three children before they started taking rhGH, and remained above this level in two children. It did not exceed this level in any other child.

\section{HORMONAL ASSESSMENT}

Results of analysis of overnight growth hormone profiles are shown in table 3 . Pulsatility was normal in all children with chronic renal failure (group 1). Of the five children in group 2 in whom overnight profiles were measured, the area under the curve was depressed in four, with severe blunting of peak amplitude in three. The sixth boy had a depressed growth hormone response to clonidine (maximum growth hormone $2.4 \mathrm{mU} / \mathrm{l})$. Three adolescents in group 3 had depressed measurements.

Concentrations of insulin like growth factor 1 were below the reference range for prepubertal children $(0.3-1.6 \mathrm{U} / \mathrm{ml})$ in all but one boy in group $1(0.22(0.05-0.48))$ and rose to within the reference range in all but one boy after treatment $(0.84(0.18-1 \cdot 42), p<0.05)$. Concentrations in group 2 all fell to within the reference range (before treatment $0.89(0.53-1.37)$; after treatment $1.08(0.64-1 \cdot 55))$. In group 3 , concentrations were within the reference range for pubertal children $(>1.0 \mathrm{U} / \mathrm{ml})$ with the exception of one boy, who lost his transplant because he did not take his drugs regularly, and may not have been taking his rhGH regularly either (before treatment $1.29(0 \cdot 80-1 \cdot 62)$, after treatment $1.73(0.06-2.64))$.

Thyroid function tests remained normal except in one boy with cystinosis who required an increase in his dose of thyroxine.

Parathyroid hormone concentrations (reference range $<66 \mathrm{ng} / \mathrm{l}$ ) were slightly raised in three children in group 1 (65 (3-129)), two in group $2(127(14-547))$, and two in group 3 (49 (12-99)). At the end of the treatment period 
Table 3 Pulsar analysis of overnight growth hormone pulsatility. Results are expressed as mean (range)

\begin{tabular}{|c|c|c|c|c|}
\hline & \multirow{2}{*}{$\begin{array}{l}\text { Area under the curve } \\
\text { ( } m U / l \text { hour of study) }\end{array}$} & \multirow{2}{*}{$\begin{array}{l}\text { Growth hormone } \\
(m U / l)^{*}\end{array}$} & \multicolumn{2}{|l|}{ Pulses } \\
\hline & & & No & $\begin{array}{l}\text { Mean peak } \\
\text { amplitude }(m U / l)^{*}\end{array}$ \\
\hline $\begin{array}{l}\text { Group 1 } \\
\text { Group } 2 \\
\text { Group } 3\end{array}$ & $\begin{array}{ll}723 & (565-932) \\
220 & (62-354) \\
338 & (179-613)\end{array}$ & $\begin{array}{c}12 \cdot 7(10 \cdot 5-15 \cdot 5) \\
3 \cdot 9(1 \cdot 2-8 \cdot 5) \\
5 \cdot 9(3 \cdot 1-11 \cdot 1)\end{array}$ & $\begin{array}{l}5(4-6) \\
4(3-5) \\
4(2-5)\end{array}$ & $\begin{aligned} & 20 \cdot 9(16 \cdot 3-25 \cdot 7) \\
& 9 \cdot 1(2 \cdot 2-17 \cdot 9) \\
& 13 \cdot 9(8 \cdot 9-21 \cdot 2)\end{aligned}$ \\
\hline
\end{tabular}

${ }^{*}$ Growth hormone conversion factor: $1 \mathrm{mU} / \mathrm{l}=0.5 \mu \mathrm{g} / \mathrm{l}$.

they were increased in one in group 1 ( 52 (22-136)), two in group $2(180(12-822))$, and one in group 3 (49 (9-109)).

\section{DIETARY ASSESSMENT}

Parents of children with chronic renal failure reported an improvement in appetite on starting treatment with rhGH, but this impression was not confirmed by their dietary assessments, which showed no change in energy and protein intake over the year before ( $\mathrm{MJ} / \mathrm{kg}$ body weight, $0.39(0.30-0.63)$; protein in $\mathrm{g} / \mathrm{kg}$ body weight, $1.9(0.9-3.0))$ and during the period of rhGH treatment (MJ $0.35(0.25-0.50)$; protein 1.7 $(0 \cdot 8-2 \cdot 8)$ ). There was, however a significant decrease in height:weight ratio (before treatment $6 \cdot 2(5 \cdot 6-7 \cdot 6)$, after treatment $5 \cdot 7$ $(5 \cdot 1-6 \cdot 4), \mathrm{p}<0 \cdot 01)$.

\section{BIOCHEMICAL AND HAEMATOLOGICAL}

\section{ASSESSMENT}

There was no significant change in the mean haemoglobin concentration $(\mathrm{g} / \mathrm{l})$ (before treatment 121 (85-152), after treatment 110 (62-135)), the white cell count, or the platelet count.

Fasting glucose concentration (venous, plasma, mmol/l) did not change significantly and remained within the reference range $(<7 \cdot 8$ $\mathrm{mmol} / \mathrm{l})$ before treatment $4 \cdot 9(2 \cdot 5-6 \cdot 2)$, after treatment $5 \cdot 2(3 \cdot 7-7 \cdot 0)$. There was, however, a significant increase in the mean percentage of glycated haemoglobin (before treatment 6.7 $(5 \cdot 4-8 \cdot 5)$, after treatment $7 \cdot 2(6 \cdot 5-8 \cdot 3)$, $\mathrm{p}<0.002$ adult reference range $4 \cdot 9-7 \cdot 5)$. There were no significant changes in mean concentrations of urea, electrolytes, or albumin, or in results of liver function tests. Calcium and phosphate concentrations remained unchanged, except for one child in group 1 whose calcium concentration fell to $1.68 \mathrm{mmol} / \mathrm{l}$. Alkaline phosphatase activity (U/l) increased significantly (before treatment 451 (244-1068), after treatment 614 (227-1293), $\mathrm{p}<0.01$ ).

\section{Discussion}

Chronic renal failure presenting in infancy commonly results in severe growth retardation..$^{10-13}$ Catch up growth can be achieved in some of these infants with correction of fluid, electrolyte, and acid base imbalance, attention to energy and protein intake, and treatment or prevention of renal osteodystrophy. ${ }^{1}$ For reasons that are not understood, however, a few infants continue to grow poorly despite intensive medical intervention. After 2 years of age, normal growth rates are usual but catch up growth is rare. ${ }^{1}$

Treatment with rhGH produced significantly improved growth in our group of children with chronic renal failure (group 1), confirming the results of a small preliminary study..$^{5}$ Our children were selected because they had the lowest height SD scores among children attending the chronic renal failure clinic, and were failing to show catch up growth despite theoretically optimum medical management. It was not possible to match them with controls because of the large number of variables (for example, diagnosis, age of onset of chronic renal failure, and severity of chronic renal failure). Such rates of growth have, however, never before been achieved by any other means and are of such magnitude that a controlled trial of the short term effects of rhGH on the growth of children with conservatively managed chronic renal failure has become unnecessary.

How rhGH exerts its effect in patients with uraemia is unknown. It may be that supraphysiological doses of rhGH are necessary to overcome peripheral resistance to the effect of growth hormone. ${ }^{14}$ This theory is supported by the rise in insulin like growth factor 1 concentration seen in our patients. It may be that rhGH stimulates food intake and protein anabolism, as an improvement in food utilisation has been noted in uraemic rats treated with rhGH..$^{15} 16$ The improved growth rate with unchanged energy and protein intake in our patients suggests that an increase in the efficiency of food utilisation had occured.

Treatment with rhGH also produced a significant increase in the rate of growth in prepubertal patients with transplants (group 2), although in this group the changes were less obvious. Catch up growth usually occurs in prepubertal children after transplantation, but steroids may interfere with the onset and progress of puberty and the pubertal growth spurt so that a decline in growth rate during the peripubertal years is common. ${ }^{217}$ This decline in growth rate is associated with depression of the spontaneous secretion of growth hormone as was seen in the patients in this study. ${ }^{2}$ The less obvious response to rhGH in this group was likely to be due to steroids. We could not find an association between the dose of steroid and the response to rhGH, or between the severity of suppression of spontaneous growth hormone secretion and response to rhGH, but this may be because of the small numbers in our study. A larger dose of rhGH might overcome the steroid effect and improve growth rates further.

Results for the pubertal patients with transplants (group 3) are less easy to interpret because of the possible confounding effect of the pubertal growth spurt. We have previously reported, however, that pubertal growth is depressed in patients taking steroids. ${ }^{2}$ The optimum management of this group of patients remains difficult. Compliance was also less certain in the adolescents; two patients definitely did not take their drugs regularly. Only one young child abandoned treatment because of fear of injections. All were offered topical local anaesthetic cream, but this was only used by one. 
Treatment with rhGH increased the rate of growth of children with renal disease in the short term, but it is not known whether it improves height prognosis. Bone age remained delayed after treatment, but there was no significant change in height SD score for bone age, suggesting that ultimate height may be unaffected. This question could only be answered by a long term controlled trial, which would be difficult-if not impossible-to do.

The treatment is not without potential side effects, and these may be of particular relevance to children with renal disease. Most importantly, it is possible that rhGH may precipitate a deterioration in renal function by several mechanisms. Firstly, it may produce hyperfiltration by increasing glomerular filtration rate and renal plasma flow. ${ }^{18}$ Secondly, hypercalciuria occurs in rats with chronic renal failure treated with rhGH who are also taking 1,25-dihydroxyvitamin $\mathrm{D}_{3} .{ }^{19}$ Thirdly, hypertension occurs in patients with acromegaly. ${ }^{20}$ Finally, growth hormone has been reported to enhance immune fuction, ${ }^{21}$ which is a potential problem for patients with renal transplants. It is not possible to say whether the decline in renal function in the two patients in our study was caused by the rhGH. One child developed worsening of her hypertension, but hypercalciuria was not a problem, and there was no increase in the incidence of rejection episodes of transplanted kidneys.

Another potential complication is an adverse effect on carbohydrate metabolism. Children with uraemia have abnormal insulin metabolism, ${ }^{14}$ and rhGH may be additive to the diabetogenic effect of steroids. The increase in the percentage of glycated haemoglobin suggests that there had been an increase in the mean blood glucose concentrations throughout the day. Changes in glycated haemoglobin have not been reported in children treated with rhGH who had normal renal function, and we known of no published results of glycated haemoglobin concentrations in children treated with rhGH who are taking steroids for other reasons. The change in our patients was not clinically important, however, and could not be detected by a change in fasting blood glucose concentration.

One patient with chronic renal failure developed hypocalcaemia. This probably resulted from inadequate calcium intake from a diet restricted in dairy products in a rapidly growing child. Calcium depletion could lead to unrecognised bone disease, which may be easily missed as a rise in alkaline phosphatase activity is expected as a reflection of the increased rate of growth.

Finally, growth hormone is known to be a mitogen. ${ }^{22}$ Children with renal transplants are more susceptible to tumour formation because of immunosuppression. Longer experience of the use of rhGH in this group of children is necessary before the risks of tumour formation can be determined.

In conclusion, rhGH is useful in improving the rate of growth of children with chronic renal failure but, in view of possible side effects, should only be considered in those who are below the third centile for height and have failed to show catch up growth when energy intake is adequate, electrolyte and acid base balances are normal, and bone disease is controlled. In these children, the benefits of improved growth may outweigh the risks of a deleterious effect on renal function. Poor growth in patients with renal transplants is usually the result of treatment with steroids, and the first approach should be to reduce the dose of steroids to a minimum. Few young children fail to show catch up growth after transplantation, but those who continue to grow at a low velocity below the third centile on the smallest possible steroid dose may benefit from rhGH. Older children whose rate of growth is decreasing in association with delayed puberty as a result of treatment with steroids should be kept under review for a year. If the rate of growth continues to decrease, rhGH may be offered. In all patients with transplants the potential side effects must be considered carefully with the patient and parents.

Long term consequences and the effect on final height are unknown.

We thank Kabi Peptide Hormones for providing the Genotropin, Jenny Jones for carrying out the hormone estimations, Les Cox or making the bone age measurements, Kate Start for doing the dietary assessments, Andrea Collins for measuring the glycated haemoglobin concentrations, and Moira Clarke and Bernadette Dix for their help with organisation.

1 Rees L, Rigden SPA, Ward GM. Chronic renal failure and growth. Arch Dis Child 1989;64:573-7.

2 Rees L, Greene SA, Adlard P, et al. Growth and endocrine function after renal transplantation. Arch Dis Child 1988; 63:1326-32.

3 Offner G, Hoyer PF, Jüppner H, Krohn HP, Brodehl J. Somatic growth after kidney transplantation. Beneficial effect of cyclosporine in comparison with conventional immunosuppression. Am 7 Dis Child 1987;141:541-6.

4 Hindmarsh PC, Brook CGD. Effect of growth hormone on short normal children. Br Med f 1987;295:573-7.

5 Lippe B, Fine RN, Koch VH, Sherman BM. Accelerated growth following treatment of children with chronic renal failure with recombinant human growth hormone (Somatrem): a preliminary report. Acta Paediatr Scand 1988; 343(suppl): 127-31.

6 Tanner JM. Growth at adolescence. 2nd Ed. Oxford: Blackwell, 1962.

7 Tanner JM, Whitehouse RH, Cameron NC, Marshall WA, Healy MJR, Goldstein H. Assessment of skeletal maturity and prediction of adult height (TW2). London: Academic Press,
1983 .

8 Tanner JM, Whitehouse RH, Takaishi M. Standards from birth to maturity for height, weight, height velocity and weight velocity: British children, 1965. Part II. Arch Dis Child 1966;41:613-35.

9 Schwartz GJ, Haycock GB, Edelmann CM. A simple estimate of glomerular filtration rate in children derived from body length and plasma creatinine. Pediatrics 1976;58:259-63.

10 Kleinknecht C, Broyer M, Huot D, Marti-Henneberg C, Dartois A-M. Growth and development of non-dialysed children with chronic renal failure. Kidney Int 1983;24:
S40-7.

Rizzoni G, Basso T, Setari $M$. Growth in children with chro-
nic renal failure on conservative treatment. Kidney Int 1984;26:52-8.

12 Polito C, Greco L, Totino SF, et al. Statural growth of children with chronic renal failure on conservative treatment. dren with chronic renal failure on conse
Acta Paediatr Scand 1987;76:97-102.

13 Claris-Appiani A, Bianchi ML, Bini P, et al. Growth in young children with chronic renal failure. Pediatr Nephrol 1989;3: childre.

14 Rees L, Chantler C. Hormonal alterations that affect the growth of children with chronic renal failure. In: Davidson AM, ed. Proceedings of the International Society of Nephro logy. Vol II. London: Ballière Tindall, 1988

15 Mehls O, Ritz E, Hunziker E-B, Eggli P, Heinrich U, Zapf J. Improvement of growth and food utilisation by human recombinant growth hormone in uraemia. Kidney Int 1988;33:45-52.

16 Powell DR, Rosenfeld RG, Hintz RL. Effects of growth hormone therapy and malnutrition on the growth of rats with renal failure. Pediatr Nephrol 1988;2:425-30.

17 Van Diemen-Steenvoorde R, Donkerwolcke RA, Brackel $H$ et al. Growth and sexual maturation in children after kidney transplantation. $\mathcal{F}$ Pediatr 1987;110:351-6.

18 Hirschberg R, Rabb H, Bergamo R, Kopple JD. The delayed effect of growth hormone on renal function in humans. Kidney Int 1989;35:865-70.

19 Kainer G, Nakano M, Boyle F, Foreman JW, Chan JCM Severe hypercalciuria as a result of combined 1, 25-dihydroxy vitamin $\mathrm{D}_{3}$ and growth hormone in uremic 1, 25-dihydroxy vitamin $\mathrm{D}_{3}$ and grodiatr Res 1989;342A:2033.

20 Underwood LE. Report of the conference on uses and possible abuses of biosynthetic $\mathrm{HGH}$. N Engl f Med 1984;311: 606-8.

21 Fabris $N$, Pierpaoli $W$, Sorkin E. Hormones and the immunological capacity. Clin Exp Immunol 1971;9:227-40. 2 Clayton PE, Gattamaneni HR, Shalet SM, Price DA. Does growth hormone cause relapse of brain tumours? Lancet growth hi:711-3. 